\title{
THE SIGNIFICANCE OF PORTFOLIO ASSESSMENT IN EFL CLASSROOM
}

\author{
Rezqan Noor Farid ${ }^{1}$
}

\section{Pendidikan Bahasa Inggris Universitas Muhammadiyah Banjarmasin rezqanfarid@gmail.com $(085754001302)$}

\begin{abstract}
The tendency of test maker and test developer in using conventional test items for students' assessment fails the objective of the assessment itself since they do not represent activities students typically perform in classrooms. The alternative for this problem is portfolio assessment. Portfolio as a purposeful collection of students' work that demonstrates their effort, progress, and achievements in given area can be used to measure the progress and achievement of students. This study is intended to reveal the significance of portfolio in assessing students' achievements. This study is conducted using Ex Post Facto design with Causal Comparative approach. The research is conducted by choosing two classes of $10^{\text {th }}$ grades in MAN 2 Martapura which used portfolio assessment and traditional assessment. The data are collected through observation and documentation consisting of number of the students, pre-test English score, and the score of final test. The result shows that the difference of assessment process the differences of student's learning achievement between the two classes which use portfolio assessment and the class which use traditional assessment.
\end{abstract}

Keywords: assessment, portfolio, students' achievement.

\section{INTRODUCTION}

\section{A. Background}

Well-designed assessment is essential to help students in learning English as their second or foreign language. Assessment is involved at many steps in helping students to reach their goal in learning English. However, test maker and test developer tend to use traditional test items to assess the students achievement which is fail to assess students' skills in school or work settings. This is in line with Herman (1992) statement that traditional test items are not authentic because they do not represent activities students typically perform in classrooms. They also do not reflect current theories of learning and cognition and are not based on abilities students actually need for future success.

Portfolio is an alternative to assess students' progress and achievement which can represent every aspect students do in the classroom. It is suggested that the word portfolio originates from the Italian word 'portare fogliou' which means to carry paper (Rassin et al. 2006 in Farrel, 2008). In communicative language teaching, portfolio development is popular alternatives in assessment. Portfolio as a purposeful collection of students' work that demonstrates their effort, progress, and achievements in given area can be used to measure the progress and achievement of students (Genesee and Uphsur: 1996). Brown (2004) stated that to 
show their progress in language learning. Students can include these materials below in their Portfolio:

(1) Essay and composition in draft and final form.

(2) Report, project outlines.

(3) Poetry and creative prose.

(4) Artwork, photos, newspaper or magazine clippings.

(5) Audio and/ or video recordings of presentation, demonstration, etc.

(6) Journal, diaries, and other personal reflections.

(7) Test, test score, and written homework exercise.

(8) Notes on lectures.

(9) Self and peer - assessment, comment, evaluation, and checklists.

Portfolio also can be a collection of works that are associated with concepts students are required to learn. This collection of work is often gathered over a long period of time to reflect what teacher has been taught as well as what students have learned. Each piece in the portfolio is required to be an authentic reflection of what students has learned and is meant to reflect students' current knowledge and skills. The main purposes of this research are find out the implication of portfolio in the EFL classroom, the description of student's learning achievement with portfolio assessment, and the difference between the students' learning achievement with traditional assessment and portfolio assessment.

\section{B. Portfolio}

A portfolio is a collection of evidence that demonstrates learning and knowledge. Farrell (2008) showed that as a medium for recording learning achievements, a student portfolio can be a catalyst for growth by providing evidence not only of the product of accomplishments, but also of the actual process of development. The use of portfolio to assess student progress, achievement, and enhancement in language learning is comprehensive and acceptable. However, portfolio is still considered to only be applicable to young learner who assembles a portfolio of artwork and written book for presentation to teacher and/ or parent.

A suggestion in developing scheme for considering the nature and purpose of portfolio is proposed by Gottlieb (1995), who use acronym CRADLE to designate six possible attributes of portfolio: Collecting, Reflecting, Assessing, Documenting, Linking, and Evaluating.

Collection means portfolio as an expression of student' live and identities. Students have freedom to choose what should include but still in the purpose of portfolio. Reflecting has meaning of practice towards journal and self assessment checklist. While assessing stands for how serious teacher and student evaluate the quality and development of students' portfolio. Documenting means portfolio is demonstrating students achievement, and not only to test and grades the students. As a link, portfolio connects students to teacher, parent, and fellow students, by a product which is created with pride, and the uniqueness of a student. The last is evaluation, which shows a time consuming but fulfilling process of generating accountability (Gottlieb: 1995). 
Based on Danielson and Abrutyn (1997) there are 3 types of portfolios that can be used in classroom. First, a portfolio can be in form of Working Portfolio which is containing students' work in progress as well as finished samples of students' work. The major purpose of a working portfolio is to be a saving bank for student work. In addition, the working portfolio may be used to diagnose student needs. The working portfolio is reviewed as a whole and by its pieces. It will be evaluated - either periodically or at the end of the learning unit. Students must reflect seriously on their work and what it demonstrates about them as learners. As students and their teachers look through the portfolio, they set shortterm objectives for achieving certain curriculum goals. The portfolio thus provides evidence of strengths and weaknesses and serves to define the next steps in learning.

The Second form of portfolio is Display, Showcase, or Best Works Portfolios. It is used to demonstrate the highest level of achievement attained by the student. Collecting items for this portfolio is a student's way of saying "Here's who I am. Here is what I can do."

There are many possibilities for the contents of a display portfolio. Students should choose types of items put in their portfolio of best works-a drawing they like, a poem they have written, a list of books they have read, or a difficult problem they have solved. Their choices define them as students and as learners. In making their selections, students illustrate what they believe to be important about their learning, what they value and want to show to others.

The third is Assessment Portfolio. Primary function of an assessment portfolio is to document what a student has learned. The primary purpose of an assessment portfolio is to document student learning on specific curriculum outcomes. The items in the portfolio should be designed to elicit the knowledge and skill specified in the outcomes. Assessment portfolios may be used to demonstrate mastery in any curricular area. They may span any period of time, from one unit to the entire year. And they may be dedicated to one subject or many subjects.

Birgin \& Baki (4: 2007) stated that there are a closely related and equally affected three aspects in using portfolio as main assessment in the classroom, they are as follows;

The first is point out the purpose of the portfolio. The purpose of the portfolio will determine the process in which it is made and kinds of item included in it. Determined purpose of portfolio will avoid overload and over generalize one. The purpose can be defined based on the users' needs. The objective of using portfolio is to assess the progress of the student on certain period of time, to show the efficiency of the teaching, to establish communication with the parents of the students, to assess the program, etc. In short, it is so important to choose the purpose since it will affect the way to collect the items, and the quality of the items.

The second is point out the items to be included in portfolio. Regarding the purpose of the portfolio, it can be taken as the basis to point out the items that should be collected, the person to collect them, the interval for each collection, and how to assess them. It is important to establish continuous communication with the students to build their responsibilities. Each item should also be tagged with certain information such as its description and the reason why it is chosen as 
the evidence. The tag will make students aware of their learning progress as they share what they can prove they know. There is no restriction on the content or items included in a portfolio. For example, a portfolio organized by a student can contain a lot of visual or activity materials such as individual or group studies, his/her best studies, tests, projects, presentations, control lists, problem solutions, questionnaire, teacher comment, reading list and reviews, self-assessment/peerassessment checklist, interview notes, course note, cd and disks.

The third is determining the assessment criteria. It is very important to determine the criteria for assessing the portfolio. Because an assessment criterion allows students to recognize, and select work that is considered high quality. It also allows and encourages discussions among teachers, students, and other concerning the outcomes and quality of outcomes. Assessment criteria which have been used to determine the quality of the student's performance should be clear and easy to understand. This is quite important in terms of student to assess his own works and to be able to fulfill his weaknesses. Rubrics should be used in order to determine quality of the evidence in portfolio and to make a reliable and valid assessment.

In other words, in portfolio preparation there are necessary steps to do; students' ideas is strongly considered, the purpose should be clear, assessment should explained clearly, the process could be finished on a certain time period, portfolio should enhance students learning attitude, and items in the portfolio should be multi-dimensional and address different learning fields. It is very important to design a portfolio which can present students' performance and development in any time period in detail.

Below are the comparison of portfolio and standardized test. (taken from Birgin \& Baki / TÜFED-TUSED / 4(2) 2007):

\begin{tabular}{|c|c|}
\hline $\begin{array}{l}\text { Portfolio Assessment TM } \\
\text { - occurs in the child's natural environment } \\
\text { - provides an opportunity for student to } \\
\text { demonstrate his/her strengths as well as } \\
\text { weaknesses }{ }^{\mathrm{TM}} \\
\text { - gives hands-on information to the teacher } \\
\text { on the spot TMTM } \\
\text { - allows the child, parent, teacher, staff to } \\
\text { evaluate the child's strengths and } \\
\text { weakness } \\
\text { - is ongoing, proving multiple opportunities } \\
\text { for observation and assessment TMTM } \\
\text { - assesses realistic and meaningful daily } \\
\text { literacy tasks } \\
\text { - invites the child to be reflective about } \\
\text { his/her work and knowledge } \\
\text { - invites the parents to be reflective of } \\
\text { child's work and knowledge } \\
\text { - encourages teacher-student conferencing } \\
\text { - informs instruction and curriculum; places } \\
\text { child at centre of the educational process }\end{array}$ & $\begin{array}{l}\text { Standardized Testing } \\
\text { - is an unnatural event } \\
\text { - provides a summary of child's } \\
\text { filatures on certain tasks } \\
\text { - provides little diagnostic information } \\
\text { - provides ranking information } \\
\text { - is an one-time "snapshot" of a } \\
\text { student's abilities on a particular task } \\
\text { - assesses artificial task, which may } \\
\text { not be meaningful to the child } \\
\text { - asks child to provide a singular } \\
\text { desired response } \\
\text { - provide parents with essentially } \\
\text { meaningless and often frightening } \\
\text { numerical data } \\
\text { - forces teacher-administration } \\
\text { conferencing } \\
\text { - reinforces idea that the curriculum is } \\
\text { the centre of the educational process }\end{array}$ \\
\hline
\end{tabular}


Table above showed that portfolio assessment can be used to measure high-level skills meaningfully and realistically, applying various assessments, assessing continuously, and pointing out the student's weaknesses and strengths. Portfolio also encourages students to join the process of assessment and establish good communication with teacher and parents. In conclusion, as portfolio is a students centred assessment, it will focus on students' achievements and reports them in detail.

\section{METHOD}

This research is conducted in Ex Post Facto design or Causal Comparative approach. The research is conducted by choosing two $10^{\text {th }}$ Grade classes in MAN 2 Martapura which used portfolio assessment and traditional assessment. The design of this research can be seen at the table below:

\begin{tabular}{|c|c|c|}
\hline Group & Independent Variable & Dependent Variable \\
\hline $1^{\text {st }}$ & $(\mathrm{X})$ & $\mathrm{Y}_{1}$ \\
$2^{\text {nd }}$ & - & $\mathrm{Y}_{2}$ \\
\hline
\end{tabular}

Table 1. Ex Post Facto Design (Furchan,1982:404)

Note :

(X) :The using of portfolio assessment that have been run;

Y1 and Y2 :The students' learning achievement

Sample of this study are chosen based on the criteria (Furchan, 1982:393) as the following:

a. Have the same English teacher with the first group;

b. Given the same material with the first group;

c. Given the same process of learning except the process of assessment;

d. Find that the classes are normally distributed, have homogeny variances, and have the same class average of English ability.

The data in this research are taken from observation and documentation consists of the number of students, pre-test score, and post-test score. The data analysis is conducted through the following steps:

(1) Doing tabulation to the first English daily test (formative test) scores.

(2) Classifying the sample based on the result of the tabulation.

(3) Interpreting the data that have been analysed. 


\section{FINDINGS AND DISCUSSIONS}

Based on the findings of the study, the researcher get the standard deviation (s) and mean (X) of students' final test score from both of the class. The mean and standard deviation of the score can be seen at the Table below.

\begin{tabular}{|l|c|c|}
\hline & $\begin{array}{c}\text { Class With Portfolio Assessment } \\
\text { (Class A) }\end{array}$ & $\begin{array}{c}\text { Class With Standard Assessment } \\
\text { (Class B) }\end{array}$ \\
\hline $\mathrm{N}$ & 42 & 45 \\
$\Sigma \mathrm{x}$ & 2953 & 2700 \\
$\Sigma \mathrm{x}^{2}$ & 220109 & 173970 \\
$\mathrm{X}$ & 70.3095 & 60 \\
$\mathrm{~s}$ & 17.4503 & 16.4938 \\
$\mathrm{~s}^{2}$ & 304.5117 & 272.0455 \\
\hline
\end{tabular}

Table 2. Average and Standard Deviation of Final Test Score of The Class

With Standard Assessment and Class With Portfolio Assessment Note:

$\mathrm{N} \quad=$ the number of the students

$\Sigma \mathrm{x} \quad=$ the sum of the score

$\Sigma \mathrm{x}^{2} \quad=$ the sum of the score's square

$\mathrm{X}=$ mean

$\mathrm{s} \quad=$ standard deviation

$\mathrm{s}^{2} \quad=$ standard deviation's square

From the table above, it is clear that the percentages of the score of the students in Class A are in balance, but the scores of students in Class B are low. The reason is almost $50 \%$ of the students in Class B get unsatisfactory scores.

To find out the differences are significance or not, the researcher analyse the difference between two classes are using t-test method. After analyse the data by using t-test at the level of significance $(\alpha) 0.05$, the researcher found out that $t_{\text {ratio }}$ is bigger than $t_{\text {table, }}$, that is $t_{\text {ratio }}=2.833>t_{\text {table }}=1.992$, which shows that there is a significant difference between the students' learning achievement with standard assessment and portfolio assessment.

The difference of assessment process at class A and class B causes the differences of student's learning achievement between the two classes which use portfolio assessment and the class which use standard assessment. In the class B, teacher and students do not make documentation of student's score and do not record the student's work. While, at class A, teacher and students always make documentation of student's score and record the student's work, so both teacher and students know the student's learning progress time to time.

The knowledge of the students' progress of learning helps teacher in choosing the method used in the classroom. This awareness also helps students finding their weaknesses and quickly solved them.

Furthermore, the use of portfolio in the subject classroom yields several findings as the following: 
The significance of Portfolio Assessment in the subject classroom TM

- occurs within students' natural environment

- provides an opportunity for student to demonstrate his/her strengths as well as weaknesses ${ }^{\mathrm{TM}}$

- gives hands-on information to the teacher on the spot TMTM

- allows the students, parent, teacher, staff to evaluate the students' strengths and weakness

- is ongoing, proving multiple opportunities for observation and assessment

- assesses realistic and meaningful daily literacy tasks

- invites the students to be reflective about his/her work and knowledge

- invites the parents to be reflective of students' work and knowledge

- encourages teacher-student conferencing

- informs instruction and curriculum; places students at centre of the educational process

As can be seen on the figure above, the use of portfolio in classroom gives opportunities to the students in using their language knowledge within natural context. This is related to the requirements for collecting real data and material. The individual and unbounded process of collecting data and processing them according to the instruction given by the teacher let the students show their strength, weakness, and interest. As students show their strength and weakness, teacher can directly grasp them and provides real - time feedback. The information on students' weakness, strength and students feedback can be directly sent to parents.

The portfolio provides many chances to do multiple evaluation and measurement along the study term. The evaluation and measurement can be done on regular or random basis depends on teaching and learning needs. The feedback given by the teacher can help the students to do self-reflection on their progress. This will lead to active communication between students and teacher.

However, the use of portfolio in classroom also has several weaknesses. They are including:

1. It is hard to control and maximize the timing of learning process. It is because the material can be expanded regarding the needs and teaching and learning process.

2. There are some indiscipline students. They tend to submit out of due date or even did not submit the task at all. This will take time and effort to fix so the students will follow the procedure correctly.

\section{CONCLUSIONS AND SUGGESTIONS}

It can be concluded that the student learning achievement with portfolio assessment is better than the student learning achievement with standard assessment at the level of believe 95\%. There are also weaknesses found which are: timing management that hard to achieve since the material can be expanded for bigger need and there are some indiscipline students who tend to submit out of due date or even did not submit the task at all. This will take time and effort to fix so the students will follow the procedure correctly. This research describes the student's learning achievement with standard assessment and portfolio 
assessment. Based on the result of this research, researcher has the recommendation as follows:

1. In using portfolio assessment, teacher should have well preparation for the materials, assignments, and another activity, which is appropriate with the time allocation.

2. Portfolio assessment is better implemented in small class because it will be easier in managing the class.

\section{REFERENCES}

Arter, J.A. \& Spandel, V. (1992). "Using Portfolios of Student Work in Instruction and Assessment. Educational Measurement: Issue and Practice”, 11(1), 36-44.

Baki, A. \& Birgin, O. (2004). "Reflections of Using Computer-Based Portfolios as an Alternative Assessment Tools: A Case Study". The Turkish Online Journal of Educational Technology, 3 (3), Article 11, http://www.tojet.net/articles/3311.htm

Barton, C. \& Collins, A. (1997). "Portfolio Assessment: A Handbook for Educators". New York: Dale Seymour Publications.

Brown, H. D. (2004). "Language Assessment: Principles and Classroom Practices". New York: Pearson Education, Inc

Chen, G.D, Liu, C.C., Ou, K.L. \& Song, L. M. (2000). “Web Learning Portfolios: A Tool for Supporting Performance". Innovations in Education and Teaching International, 38 (1), 19-30.

Cicmanec, K.M. \& Viecknicki, K.J. (1994). "Assessing Mathematics Skills through Portfolios: Validating the Claims from Existing Literature". Educational Assessment, 2(2), 167-178.

Collins, A. (1992). "Portfolios in Science Education: Issue in Purpose, Structure and Authenticity". Science Education, 76 (4), 451-463.

De Fina, A. (1992). "Portfolio Assessment: Getting Started". New York: Scholastic Professional Books.

Danielson, C. \& Lesly, A. (1997). "Introduction to Using Portfolios in the Classroom”. Association for Supervision \& Curriculum Development.

De Fina, A. (1992). "Portfolio Assessment: Getting Started". New York: Scholastic Professional Books.

Dochy, F. (2001). A New Assessment Era: Different Needs, New Challenges. Learning and Instruction, 10 (1), 11-20.

Farrell, Miriam. (2008). Purpose of Portfolio. In Making Sense of Portfolios: a Guide for Nursing Students. By Fiona Timmins (2008). Berkshire: Open University Press. 
Fourie, I. \& Van Niekerk, D. (2001). "Follow-Up on the Portfolio Assessment a Module in Research Information Skills; An Analysis of its Value". Education for Information, 19, 107-126.

Geathart, M. \& Herman, J.L. (1995). "Portfolio Assessment: Whose Work is it? Issues in The Use Of Classroom Assignments For Accountability". National Center for Research on Evaluation, Standards, and Student Testing, University of California, Los Angeles.

Gilman, D.A., Andrew, R. \& Rafferty, C.D. (1995). "Making Assessment a Meaningful Part of Instruction". NASSP Bulletin, 79 (573), 20-24.

Grace, C. (1992). "The Portfolio And Its Use: Developmentally Appropriate Assessment of Young Children". Eric Digest. ED351150.

Gay. L.R. (1992). Educational Research: Competencies for Analysis and Application. Fourth Edition. Macmillan Company. New York.

Genesee, F \& Uphsur, John. A. (1996). "Classroom based evaluation in second language education”. Cambridge: Cambridge University Press.

Gottlieb, M. (1995), "Nurturing Students Learning through Portfolios", TESOL Journal.

Haladyna, T.M. (1997). “Writing Test Items to Evaluate Higher Order Thinking”. USA: Allyn \& Bacon.

Herman, J.L. \& Winters, L. (1994). "Portfolio Research: A Slim Collection. Education Leadership”, 52 (2).

Hamp-Lyons, L \& Condon, W. (2000). Assessing Portfolio: Principles for Practice Theory and Research. Cresskill, NJ: Hampton Press.

Herman, J. L. \& Winters, L. (1994). "Portfolio Research: A Slim Collection". Education Leadership, 52

Jones, M \& Shelton, M (2011) Developing Your Portfolio: Enhancing Your Learning and Showing Your Stuff: A Guide for the Early Childhood Student or Professional Second Edition. New York: Routledge.

Klenowski, V. (2000). "Portfolios: Promoting Teaching. Assessment in Education, Police \& Practice". 7(2), 215-236.

Koretz, D., Stecher, B., Klein, S. \& McCaffrey, D. (1994). "The Vermont Portfolio Assessment Program: Findings and Implications". Education Measurement: Issues and Practice, 13 (5), 5-16.

Korkmaz H. \& Kaptan, F. (2005). "An Investigation On Using Electronic Portfolio For Assessing Students' Development In Science Education". The Turkısh Onlıne Journal of Educational Technology (TOJET), 4 (1), 101-106. http://www.tojet.net/v4il.pdf

Lankes, A.M.D. (1995). “Electronic Portfolios: A New Idea in Assessment”. Eric Digest, ED390377.

Lustig, K. (1996). "Portfolio Assessment: A Handbook for Middle Level Teachers". Columbus: National Middle School Association. 
Melograno, V.J. (2000). "Designing a Portfolio System for K-12 Physical Education: A Step-By-Step Process". Measurement in Physical Education \& Exercise Science, 4(2), 97-116.

Moya, S.S., \& O'Malley, J.M. (1990). “A Portfolio Assessment Model for ESL”. Journal of Educational Issues of Language Minority Students.

Palmer W, D. (1992). "Good Measure: Assessment as a Tool for Educational Reform". Educational Leadership

Paulson, F.L, Paulsun, P. \& Meyer (1991). “What Makes a Portfolio?”. Educational Leadership.

Singh, Y, K. (2006). Fundamental of Research Methodology and Statistics. New Delhi: New Age International (P) Ltd.

Simon, M. \& Forgette-Giroux, R. (2000). "Impact of a Content Selection Framework on Portfolio Assessment at the Classroom Level". Assessment in Education.

Stiggins, R.J. (1990). "The Foundation of Performance Assessment: A Strong Training Program" (Policy Briefs Nos. 10 and 11). Oak Brook, IL: North Central Regional Educational Laboratory.

Tierney, R.J., Carter, M.A., \& Desai, L.E. (1991). "Portfolio Assessment in the Reading-Writing Classroom". Norwood, MA: Christopher Gordon Publishers.

Valencia, S.W. (1990). "Alternative assessment: Separating the wheat from the chaff'. The Reading Teacher.

Winsor, P. \& Ellefson, B. (1995). "Professional Portfolios in Teacher Education: An Exploration of Their Value and Potential". The Teacher Educator.

Wolcott, W. (1998). "an Overview Writing Assessment: Theory, Research, and Practice". Urbana, IL: National Council of Teacher of English. 